\title{
CESIS
}

Electronic Working Paper Series

Paper No. 56

\section{Industrial effects on resource acquisition: Immigrant enterprises in Kista, Stockholm ${ }^{1}$}

Tobias Dalhammar (KTH) and Terrence E. Brown (KTH)

Dec 2005

The Royal Institute of technology

Centre of Excellence for studies in Science and Innovation http://www.infra.kth.se/cesis/cesis/publications/working_papers/index.htm

Corresponding author: tobiasd@imit.kth.se

${ }^{1}$ Status of the paper: The paper was rewarded Best PhD Student Paper at the Uddevalla Symposium 2005. 


\title{
Industrial effects on resource acquisition:
}

\section{Immigrant enterprises in Kista, Stockholm}

\author{
by \\ Tobias Dalhammar* and Terrence E. Brown**
}

Dec 2005

\begin{abstract}
This paper is based on seven in-depth case studies of small businesses in Kista, Stockholm's most northern district. This district provides an interesting example with its high technology setting, mixed with considerable numbers of immigrants living in the area. All the firms are led by people who have immigrant background, and therefore they all have ethnic minority backgrounds, either in terms of country of origin or as belonging to a definable ethnic group. The guiding question is if one can find differences between high tech and service-based immigrant businesses in terms of how they use ethnic resources in their resource acquisition efforts. In the case studies we explore (i) how ethnic resources contribute to the acquisition of crucial resources for these firms, and (ii) the utilization of ethnic resources indicates the influence and importance of ethnic minority background for immigrant businesses in different industries. The results show differences in what sources these firms use for acquiring resources. The service-based firms utilise ethnic resources to a greater extent than the high tech firms. These differences influence the importance of the business owners' ethnic minority backgrounds.
\end{abstract}

JEL codes: L10, L20, L70, L80

Keywords: Immigrant and ethnic entrepreneurship, high tech/science-and technologybased firms, service-based firms, resource acquisition, ethnic resources.

* Royal Institute of Technology, Isafjordgatan 39, P.O. Box 229, 16440

Kista, Sweden. Phone: +46 87904281. E-mail: tobiasd@imit.kth.se.:
* Royal Institute of Technology, Isafjordgatan 39, P.O. Box 229, 16440

Kista, Sweden.. Phone: +46 87904199. E-mail: terrence@kth.se 


\section{Introduction}

The number of companies run by immigrants and ethnic minority entrepreneurs in Sweden is almost three times the level of 10-15 years ago (SOU, 1999). In 1998, there were about 65.000 immigrant enterprises in Sweden. Proportionally, the number of immigrant and ethnic businesses is still below the general population. However, the number of ethnic enterprises is rising, since around 20 per cent of all new firms in Sweden 2001 were founded by people "descending from other countries", which is the official definition for an immigrant entrepreneur" ${ }^{2}$. These companies are slightly overrepresented in the service sector compared to the manufacturing sector, 21 and 17 per cent, respectively. Furthermore, there are important regional differences. The highest numbers are found in the four counties ("län") of Stockholm, Södermanland, Västmanland and Skåne, where the number of immigrant start-ups was about 25 per cent in 2001. Reasons for starting businesses are similar to those of mainstream (i.e. majority) entrepreneurs, e.g. independency and fulfilling ones ambitions, with the exception that a higher amount of immigrant/ethnic entrepreneurs start a business as a means of avoiding or escaping unemployment (ITPS, 2002).

However, research shows that there are great differences in business activity, behaviour and performance between ethnic groups, in Sweden as well as internationally (Waldinger et al, 1990; 2000; Najib, 1999; NUTEK 2001a; 2001b; Abbasian, 2003; Mitchell, 2003). Obviously, differences also occur at the individual level (Ram and Smallbone, 2001; Abbasian, 2003). Consequently, a person is not predetermined to a certain kind of business activity just because he/she belongs to a definable ethnic group. And voices have been raised asserting that immigrant entrepreneurship is no homogeneous phenomenon (Najib, 1999; Ram and Smallbone, 2001; Chaganti and Greene, 2002), despite previous policy documents that have been presented in a rather conform way (SOU, 1999; NUTEK, 2001a; NUTEK, 2001b). For example, Najib (1999) states that immigrants run businesses in all kinds of industries and settings, including high technology environments. This also implies that there are contextual aspects to immigrant and ethnic entrepreneurship (Waldinger et al, 1990; 2000; Abbasian, 2003). This presents a view different from the established one, where restaurants and other service-related businesses, such as corner shops, are common references (Najib, 1999).

Immigrant and ethnic entrepreneurship have been researched from a variety of angles. In principle, two basic variables are commonly employed in order to explain differences in entrepreneurial activity between ethnic minority groups (Waldinger et al, 1990; 2000; Najib, 1999). The first one concerns cultural (pull) factors, which derive from ethnicity, above all collective ethnic properties. This view emphasises the meaning of entrepreneurship in different cultures, such as the propensity to enterprise in the homelands. Cultural factors in this sense equate the concept of ethnic group characteristics. The structural (push) perspective, on the other hand, studies the differences in business activities in structural factors on the labour market. One example is that immigrants in general are discriminated on the labour market. This implies that structural factors equate the meaning of contextual opportunity structures.

\footnotetext{
${ }^{2}$ In immigrant and ethnic entrepreneurship literature (SOU, 1999; Najib, 1999; NUTEK, 2001a) it is concluded that if a person has at least one parent that is born abroad, he/she should be defined as an immigrant too. If that person founds a business, he/she per definition becomes an immigrant entrepreneur and the business an immigrant business. However, the Swedish Central Bureau for statistics, SCB, has now changed that definition: in order for a person to be labelled 'immigrant', both her/his parents have to be born abroad (see http://www.uppsala.se/uppsala/templates/StandardPage 3260.aspx).
} 
Still, both cultural and structural theories have difficulties to explain why ethnic minority groups show such great differences in business activities despite the fact that discrimination generally means that ethnic minorities are treated in similar manners (Waldinger et al, 1990; 2000; Light and Gold, 2000). Therefore, a third view deals with a combination of cultural and structural factors. Some researchers (e.g. Waldinger et al, 1990; 2000) argue that cultural and structural factors overlap each other and therefore are difficult to divide. ${ }^{3}$ By this view, either culture or structure is dominant and the other complementary (Najib, 1999). This situational approach - also known as the interactive theory - deals with the relationship between cultural or social characteristics and the circumstances of their arrival and settlement (Mitchell, 2003). The decisive factors could be different for each ethnic minority group, which diminishes the possibility to use a general theoretical approach as a means of understanding immigrant and ethnic entrepreneurship.

\section{An industrial perspective on immigrant and ethnic entrepreneurship}

In the literature and debate about immigrant and ethnic entrepreneurship there often is lack of clarity concerning what these conceptions mean and include. Waldinger et al (1990:3) define ethnic entrepreneurship as “.... a set of connections and regular patterns of interaction among people sharing common national background or migration experiences". In general, "ethnic entrepreneurship" means entrepreneurship referring to certain ethnic groups, whereas "immigrant entrepreneurship" refers to entrepreneurship performed by all groups of immigrants in a country (Waldinger et al, 1990; 2000). This means that in the past and at present, entrepreneurs' self-reported ethnic origin is the most commonly used definition of ethnicity (Light, 1973; Waldinger et al, 1990; 2000; Najib, 1999).

However, Chaganti and Greene (2002) convincingly argue that - instead of ethnic origin - the owner-manager's degree of personal involvement in the ethnic community is a more accurate measure of the "ethnicity" of a business. As a result, what decides how to categorise an entrepreneur is the level of involvement among co-ethnics, i.e. utilisation of ethnic resources and thus ethnicity as a resource. The level of ethnic community involvement is a useful indicator, since it points at the dependence of a business on the ethnic community. And dependence is likely to determine whether resources available in the ethnic community determine boundaries to growth of ethnic businesses, or if owners will seek and can access and exploit opportunities available in the larger mainstream economy. In the longer run, this determines how ethnic minority background of the individual(s) involved influences the operation of their business.

As mentioned above, what ethnic entrepreneurs access by ethnic involvement is commonly referred to as "ethnic resources" (Waldinger, 1990; 2000; Light and Gold, 2000; Ram and Smallbone, 2001). Ethnic resources are socio-cultural features that coethnic business owners utilize in business or from which their businesses passively benefit. If used strategically, ethnic resources could become a competitive advantage (Ram and Smallbone, 2001). In this sense ethnicity in itself becomes a resource (Pripp,

\footnotetext{
${ }^{3}$ Waldinger et al, (1990; 2000) present an interactive model of ethnic entrepreneurship that incorporates both opportunity structures (market conditions, access to ownership) and group characteristics (predisposing factors, resource mobilisation). Ethnic strategies are assumed to arise as a response to these exogenous (structural) and endogenous (cultural) factors.
} 
2001). Despite many benefits of ethnic resources and connections (financial capital, advice, labour etc.), ethnic resources may operate within a context that may limit freedom and impose restrictions that constrain gainful activities (Light and Gold, 2000). In fact, if no other 'mainstream' resources are available, entrepreneurs may be left with no choice but to utilise ethnic resources. And these ethnic resources (e.g. labour) may not be the most qualified or suitable for the business.

Chaganti and Greene (2002:141) argue: “A high tech business run by a highly educated ethnic entrepreneur is likely to seek rapid growth and need the same types of resources as those needed by a "mainstream" owner's high tech business." And although there may be greater hindrances for immigrant/ethnic entrepreneurs, the authors claim the chances are big that they would obtain the resources necessary. This implies that high tech immigrant/ethnic entrepreneurs have similar rationales and face similar conditions as their mainstream counterparts. At the same time, Chaganti and Greene (2002) propose that small service firms anchored in ethnic communities may not have the same needs as their high tech counterparts. These service-based firms face other conditions, not to mention different rationales for engaging in business activities. Therefore, they have a tendency to draw more on ethnic resources. This suggests that type of industry or firm has an impact on the degree of ethnic community involvement, which in turn influences the utilisation of ethnic resources.

In opposition to Chaganti and Greene's (2002) suggestions above, Saxenian (2001:82) concludes: "It appears that the most successful high tech immigrant entrepreneurs in Silicon Valley today are those who have drawn on ethnic resources while simultaneously integrating into mainstream technology and business networks." The problem is that Saxenian's (2001) findings are based on research in a certain context, namely Silicon Valley in the USA. In Silicon Valley today, there exists large ethnic communities of Chinese and Asian Indian high tech enterprises, and these are the two groups Saxenian has researched. There is a great possibility that results would be different when researching high tech immigrant entrepreneurs with other ethnic backgrounds in other business contexts in the world. Thus, the value of Saxenian's (2001) study is to a great extent context-specific and cannot merely be transferred to conditions in Sweden. However, her findings imply that focus should be put on resources needed (including ethnic resources) in relation to the industry and context within which immigrant/ethnic entrepreneurs are embedded.

\subsection{Science- and technology-based vs. service-based firms}

As discussed earlier, conditions for immigrant/ethnic businesses in high-technology settings are likely to be different from those of immigrant/ethnic businesses in more 'traditional' sectors. However, the term 'high-technology' has been used with little care over the years. According to Bozkaya et al (2003) Technology-based small firms (TBSFs) are innovative enterprises also widely known as 'high-technology' start-ups. In a definition proposed by Allen (1992, in Bozkaya et al, 2003:6) ${ }^{4}$ TSBFs are "businesses whose products or services depend largely on the application of scientific and technological knowledge, or as businesses whose activities embrace a significant technology component as a major source of competitive advantage.” These start-ups are normally based on unique characteristics (as in terms of professional knowledge) of the individual venture, and these businesses are generally located in industries such as

\footnotetext{
${ }^{4}$ http://www.iir.hit-u.ac.jp/file/WP03-23bruno.pdf.
} 
aviation, communications, information technology, biotechnology, electronics and medical life sciences (Bozkaya et al, 2003).

In a similar manner, Keeble and Wilkinson (2000:3-4) refer "high-technology" (as opposed to other firms and industries) to "...firms and industries whose products or services embody new, innovative and advanced technologies developed by the application of scientific and technological expertise. Such firms almost invariably regard such expertise and resultant technological leadership as the firm's leading competitive advantage, and are usually identified in practice by high R\&D-intensity (high levels of research and development expenditure and/or employment relative to turnover or total workforce)." Note that by this definition, service firms could also be high tech businesses, albeit they need to involve innovative and advanced technologies to meet the requirements. Still, when including the aspect of advanced technology, we find this definition useful as a means of making a distinction between technology-based and service-based firms. From now on we equate the terms of high tech and science-and technology-based firms, and put them in opposition to service-based firms.

Gartner (1985) concludes that many research samples in entrepreneurship are selected without accounting for type of firm or industry. And of those studies that have taken an industrial perspective, few attempts have been made to compare firms in different industries to find out what difference type of firm might make in the process of venture creation and development. Entrepreneurs form very different kinds of organisations and it is about time entrepreneurship researchers stop talking about entrepreneurial organisations as a certain type. Differences in industrial settings and other issues mean that the kind of organisation emerging has an important impact on the development of firms.

Samuelsson's (2001) research shows there are significant systematic differences between firms exploiting innovative and those exploiting equilibrium (imitative) venture opportunities. His empirical findings reveal that innovative venture opportunities are characterised by a "specialist" strategy, tacit knowledge and are more likely to acquire specific resources needed to exploit the opportunity (utilitarian reinforcement). This activity involves the creation of new transactions. Accordingly, exploiting innovative venture opportunities is more oriented towards risk and new markets, where first mover advantage is a potential opportunity and 'liability of newness' (Stinchcombe, 1965) a potential threat. In opposition to this, exploiting equilibrium venture opportunities involves existing market transactions and such activities tend to imitate existing ventures. A market is in place and a ready concept can often be used when setting the course for the business, which means that the potential pits and downfalls are less. This implies that exploiting equilibrium venture opportunities should be a shorter and more straightforward process. The big con is the existence of heavy competition.

In relation to type of industry or firm, it seems as although the division between exploiting innovative and equilibrium (imitative) venture opportunities are applicable also for the division between science-and technology-based and service-based firms, it does not correspond in all ways. As an example, a firm that exploits an ethnic niche could be innovative in the sense that it creates a new market and explores previously unexplored terrain. However, in principle the division between innovative and equilibrium venture opportunities is applicable to type of industry or firm. Innovative 
ventures are generally high tech/science- and technology-based firms, and equilibrium ventures service-based firms.

\section{Resource acquisition and the resource-based view}

Firms interact with the surroundings because they need resources (Gartner, 1985; Light and Gold, 2000; Alvarez and Busenitz, 2001). In fact, Light and Gold (2000) regard the concept referred to as entrepreneurial capacity as just a cipher for the resources that create it. A new firm emerges when the individual(s) involved identifies/identify, assemble(s) and configure(s) resources, thus resources are one of the defining properties of new ventures, contributing to the character of the emerging organisation (Katz and Gartner, 1988; Barney, 1991; Alvarez and Busenitz, 2001). Over time, some resources are reorganised, new ones are acquired, some become specialized and others may become idle (Brush et al, 1997).

A resource acquisition perspective has its roots in the resource-based view (Penrose, 1959; Barney, 1991; 2001; Brush et al, 1997). According to this view, organisations are comprised of heterogeneous bundles of resources, defined as "all tangible and intangible assets that are tied to the firm in a relatively permanent fashion" (Brush et al, 1997), or as "all assets, capabilities, organizational processes, firm attributes, information, knowledge, etc. controlled by a firm that enable [it to] improve its efficiency and effectiveness" (Barney, 1991: 101). The acquisition of resources and their combinations provide a firm's strengths, and optimally are a source of competitive advantage (Penrose, 1959/1985; Barney, 1991; Alvarez and Busenitz, 2001). The acquisition of resources then becomes a key activity for new ventures, since these normally start out with a scarce resource base (Aldrich, 1999; Johannisson, 2000).

\subsection{Resources in relation to immigrant/ethnic entrepreneurship}

Different researchers have defined a number of resources (Greene and Brown, 1997; Greene, Brush and Brown, 1997). All resources are forms of capital (Light and Gold, 2000). In immigrant and ethnic entrepreneurship literature, resources commonly have been discussed in a way that deals with how immigrant/ethnic entrepreneurs possess and acquire so-called "mainstream" resources in relation to ethnic resources (Waldinger et al., 1990; 2000; Pripp, 2001; Saxenian, 2001; Chaganti and Greene, 2002; Abbasian, 2003). Light and Gold (2000:83-84) develop this further and make the distinction between class resources and ethnic resources. While class resources refer to social status and not to ethnic origin, ethnic resources are acquired differently and cannot be referred to resources dependent on class, which numerous examples show (Light and Gold, 2000; Pripp, 2001; Saxenian, 2001; Chaganti and Greene, 2002). Light and Gold (2000) refer to four types of capital in relation to class resources: financial, cultural, social and human capital. Immigrant and ethnic enterprises are expected to utilise both class and ethnic resources in different proportions.

Ethnic resources are socio-cultural and demographic features of a whole ethnic group from which co-ethnic entrepreneurs actively or passively benefit. Ethnic resources characterise a whole group, not just isolated members and not just high-status members. “Typical ethnic resources include kinship and marriage systems, relationships of trust, ethnic-derived social capital, cultural assumptions, religion, native language fluency, a middleman heritage, entrepreneurial values and attitudes, rotating credit associations,

\footnotetext{
${ }^{5}$ Source: http://www.babson.edu/entrep/fer/papers97/brush/bru3.htm\#BACKGROUND.
} 
relative satisfaction arising from nonacculturation to prevailing labor and living standards, reactive solidarities, multiplex social networks, employer paternalism, an ideology of ethnic solidarity, and a generous pool of underemployed and disadvantaged coethnic workers.” (Light and Gold, 2000:102). In practice, money from co-ethnics (financial capital), co-ethnic labour, ethnic traditions of business ownership/business expertise and ethnic consumer demand are the most useful measures of ethnic involvement and dependency. These resources are normally built on mutual trust (Light and Gold, 2000).

Financial capital is basically the economic resources tied to the business activity. For ethnic entrepreneurs, the ethnic community and the ethnic network often provide opportunities for financial assistance (Waldinger et al, 1990; 2000; Light and Gold, 2000). Typically, such arrangements have the character of informal borrowing and lending, sometimes with interest rates, based on mutual tacit understanding of the rules of the game. Although this kind of credit giving activities have been regarded and stated as a valuable resource exclusive for certain ethnic groups, these loans have to be paid back sooner or later, just as any other loans. And examples show that the very existence of such arrangements could indicate that these people have problems borrowing money from 'mainstream' sources (Light and Gold, 2000).

Human capital means an individual's investment in personal productivity. Formal education, such as university education and informal education, such as work experience, are the basic forms of human capital. Besides, non-formal education, like adult education, may increase an individual's human capital (Light and Gold, 2000; Davidsson and Honig, 2003). Human capital also includes a number of other variables, where e.g. language skills are suggested important for immigrant and ethnic entrepreneurs. These are referred to as knowledge and knowledge may be defined as either tacit (know-how) or explicit (know-what). Davidsson and Honig (2003:306) state that “...tacit knowledge refers to know-how, the often noncodified components of activity. Know-what consists of the explicit type of information normally conveyed in procedures, processes, formal written documents and educational institutions." Previous studies show that formal education increases the individual's likelihood of engaging in nascent activities, but that it does not determine success in the exploitation process (Davidsson and Honig, 2003).

Bourdieu (1979, in Light and Gold, 2000:91) defines cultural capital “....as competence in a society's high-status culture.” For the study of immigrant and ethnic entrepreneurship, cultural capital is best translated as the knowledge how to acquire 'mainstream' forms of capital in a society. Human capital, for example, increases its owner's productivity, a competence rewarded with higher productivity and income, whereas cultural capital reflects prestige recognition for which people get e.g. desirable educations and business contacts. This means that education or work experience could have value as both human and cultural capital. The difference depends upon whether they emphasise the real vocational experiences or the prestige recognition it means to its carrier (Light and Gold, 2000).

One definition of social capital is “...the arrangement of human resources to improve flows of future income.” (Light and Gold, 2000:94). And Davidsson and Honig (2003:307) state: "Social capital theory refers to the ability of actors to extract benefits from their social structures, networks and memberships. Social networks provided by extended family, community-based or organizational relationships are theorized to 
supplement the effects of education, experience and financial capital.” A fruitful way is to broadly utilise social capital in terms of social exchange to examine the effects of exchange ties on performance. Ties that result in social capital can occur at both individual and organisational levels, although commonly attributed to the individuals involved (Aldrich, 1999; Davidsson and Honig, 2003). Thus, access to social relations that facilitate entrepreneurship increases a person's entrepreneurial social capital and the simplest form of social capital is a network of strong (bonding) and weak (bridging) social ties (Ardichivili et al, 2003; Davidsson and Honig, 2003). "The contribution of social networks to entrepreneurship is the most important discovery in the last generation. Entrepreneurs make extensive and important use of social networks when starting and running a business.” (Light and Gold, 2000). Cultural capital includes the knowledge of what social capital is, how to obtain it and how to use it. Nevertheless, cultural capital and social capital are distinguished by the fact that cultural capital means the knowledge how to obtain and use "mainstream" resources and social capital means the actual acquisition and possession of those resources. Unlike financial capital, which decreases with use, social capital increases with use. And unlike human and cultural capital, which a learner absorbs, social capital remains an external resource. (Light and Gold, 2000).

Although all types of resources are important, when looking at resource acquisition aspects, social capital stands as extraordinarily crucial (Davidsson and Honig, 2003). A lack of social capital generally leads to a lack of other resources as well. Many researchers have emphasised the importance of social and professional networks and for businesses with scarce resources, networking more or less equates actions of resource acquisition (Aldrich, 1999; Johannisson, 2000; Johannisson, 2001; Saxenian, 2001).

\section{Conceptual framework}

Gartner (1985) presents a framework including four perspectives/dimensions in order to understand early firm development: the characteristics of the individual(s) involved, the organisation under creation, the environment surrounding the new venture and its influence, and the very process by which the new venture is started. Although he does not claim this framework to be complete, Gartner (1985) convincingly argues that no description of a venture is complete without taking these four perspectives into account. He suggests that an integration of these perspectives is needed to describe the multidimensional phenomenon of new venture creation. Thus, the framework provides a systematic means of comparing and contrasting complex ventures, i.e. conceptualising variation and complexity. The value of such an approach also is applicable in a narrowly selected research sample in order to avoid making too hasty conclusions about the virtual sameness of businesses in a sample (Gartner, 1985).

In our conceptual framework for this study, we use Gartner's (1985) framework and specifically focus on some aspects related to each dimension in the framework. Those aspects will be emphasised in the remainder of this paper. They are all connected to the discussions conducted above. Although many matters are of interest, we specifically focus on aspects that can be related to type of industry or firm (the organisational dimension), proactive behaviour of the individual(s) involved (the individual dimension), interaction with actors in the business support system (the environmental dimension) and to firm-specific aspects of resource acquisition (the process dimension). Figure 1, which is an elaboration of Gartner's (1985) framework, views the conceptual framework for this study. 


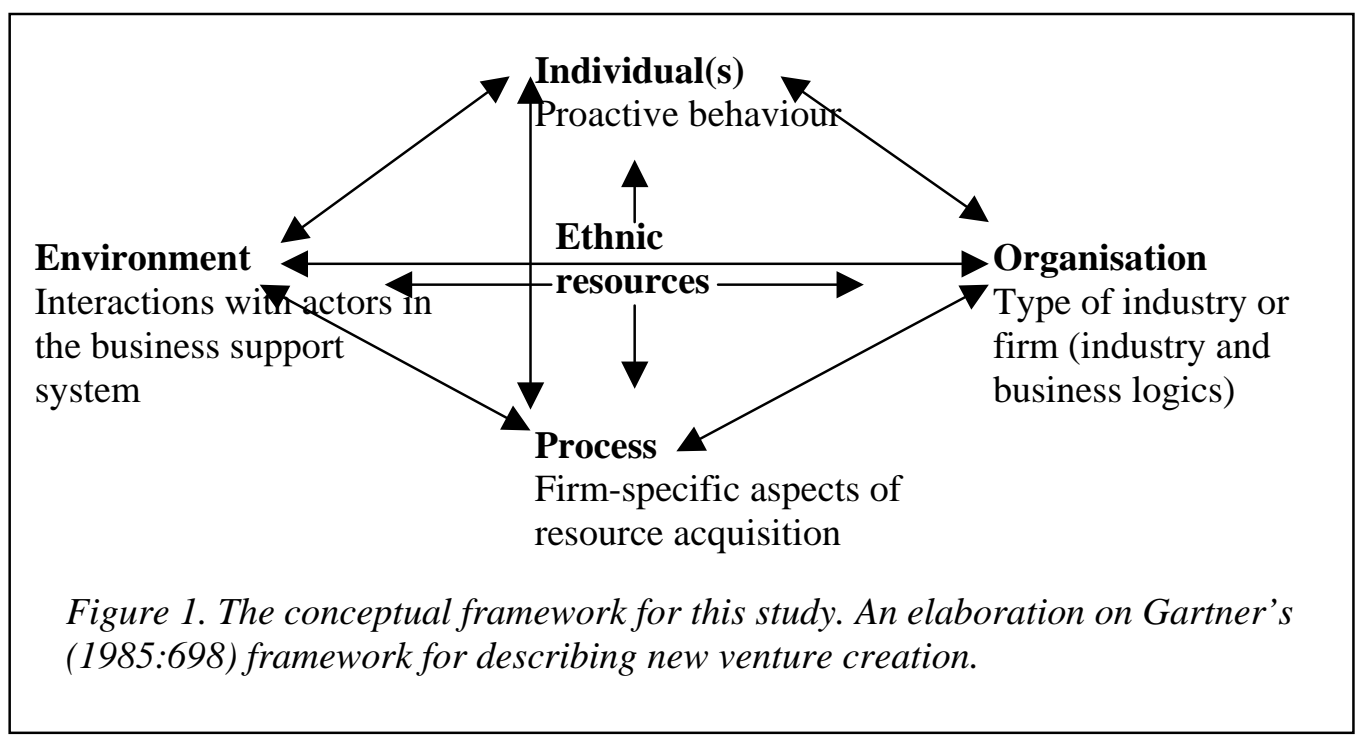

The conceptual framework incorporates important aspects of the theoretical discussion conducted above and is the "lens" through which we study the empirical context. The four cornerstones summarise a number of interactions among the dimensions: various types of resources in the resource acquisition efforts of the organisation, the individual(s) involved, the interaction with the environment and the very process by which the resource acquisition process takes place. And according to Alvarez and Busenitz (2001), who discuss the connection between entrepreneurship and the resource-based view, resources can be used as the unit of analysis in entrepreneurship studies. Resources can be studied at each dimension since a resource acquisition perspective makes it possible to practically organise these at an overall firm level. Therefore, combining the four perspectives with a resource acquisition perspective represents a theoretical as well as a methodological tool.

Type of industry or firm (industry and business logics) - represents the organisational/firm level. As previously discussed, service-based immigrant/ethnic businesses are expected to draw on ethnic resources to a higher degree than high tech immigrant/ethnic businesses, which instead are expected to draw more on "mainstream" resources (Chaganti and Greene, 2002). Proactivity deals with attitudes and behaviour of the individual(s) involved. The terms proactive and reactive behaviour reflect different behaviours towards venture opportunities (Bateman and Crant, 1993; Becherer and Maurer, 1999). A person that exerts proactive behaviour acts toward and exploits or creates opportunities, regardless if these are innovative or equilibrium in character. On the other hand, reactive behaviour means that a person does not have the same alertness to perceive and act toward opportunities (Kirzner, 1973) or to create opportunities (Schumpeter, 1934, in Swedberg, 2000; Gartner et al, 2003). Although there is practical value in separating individuals and firms, these still are intertwined and can be said to represent two sides of the same coin. Every venture opportunity, regardless of type of industry or firm, involves people and these can exhibit various degrees of proactive and reactive behaviour. In this sense, action is one of the fundamental aspects in the process of starting up, developing and running a firm (Johannisson, 2000; Holmquist, 2003; Gartner et al, 2003). The importance of actions and behaviours of individuals gives recognition to what Penrose (1959/1985) states: management is the most critical resource of all for a firm (Pitelis, 2002). 
Further, the influence of the environment is incorporated in interaction with actors in the business support system. This includes how individual(s) involved in a business engage in relationships and networking activities, above all with actors in the business support system, to acquire crucial resources (see Johannisson, 2000). Since new businesses usually start out with scarce resources (Aldrich, 1999), the interactions with and support from actors in the business support system are of utmost importance. The fourth dimension is the specific process each venture goes through and firm-specific aspects of resource acquisition. A deeper understanding of this dimension can only be obtained using a methodology that pays attention to the complexity and variation in each case, as well as listens to the individual(s) involved in the cases.

\subsection{Operationalising ethnic resources}

In the conceptual framework (Figure 1) we include ethnic resources as a means of investigating the importance of ethnic minority background in the process of acquiring resources for the development of a firm. Utilising ethnic resources affects the acquisition of all other types of resources. As mentioned before, the five most important kinds of resources in relation to ethnic resources are:

- $\quad$ Ethnic sources for financial capital, e.g. rotating credit associations.

- Ethnic sources for organisational capital, mainly labour and crucial internal business skills.

- Ethnic origin of human capital of the individual(s) involved, e.g. a historical proclivity towards business activities in certain industries and thereby through 'ethnic training' acquisition of adequate business skills.

- Ethnic consumer demand, e.g. certain kind of food or products targeted at or wanted by a definable ethnic group.

Further, one additional dimension can be added that emphasises the importance of social capital:

- Ethnic sources for social capital, e.g. business expertise and crucial intermediary relations.

These five aspects are in focus when studying the importance of ethnic resources among the firms in the empirical case studies.

\section{Study}

This paper is based on empirical case studies of seven businesses located in Kista in Stockholm, the capital of Sweden. Kista is the most northern district of Stockholm. It includes the units Kista, Akalla and Husby. Almost 30.000 people live in the Kista district and about as many people work there. Kista is an interesting area for more than one reason. First, it hosts a large concentration on ICT (Information and Communications Technology). Over a longer life cycle, the industry in Kista has expanded steadily and today there are more than 2.000 companies in the Kista district ${ }^{6}$. During the first quarter

\footnotetext{
${ }^{6}$ Source: Intranet of the municipality of Stockholm (http://info.kista.stockholm.se/1.htm).

According to recent statistics, of these 2000 around 400 are ICT companies (http://www.idg.se/ArticlePages/200401/16/20040116125725_CS/20040116125725_CS.dbp.asp?s=02222 22222222222333333333333330013333333333333300111111111111111\&nolimit=true).
} 
200426.433 people worked in Kista, whereof 17.360 in ICT companies and 9.073 in other kinds of firms. ${ }^{7}$ A common reference for this ICT focus is Kista Science City ${ }^{8}$. This technology focus is further emphasised by the fact that many ICT and knowledge intensive companies - both big (as Ericsson, Nokia etc.) and small (as those presented below in our study) - have offices located in Kista. This effort is also underlined by the joint foundation of the IT University by KTH (Royal Institute of Technology) and Stockholm University.

Second, Kista is also a district with great variation. The Kista galleria ("Kista-gallerian”) divides Kista in two different parts: Working Kista (the area where people work) and Residential Kista (the housing area where people live). Kista has an international touch in that many people have roots from countries all over the world. In fact, the number of people with foreign citizenship is 44 per cent $^{9}$. And immigrants take many business initiatives.

In our search for firms, we have tried to find businesses that cover a certain scope of business activities in different industries. Apart from high tech firms, we want to study service-based firms as a comparison. We contacted a number of actors, mainly in the business support system in Kista, who function as intermediaries to the firms. Of the seven firms in this study, four are categorised as high tech firms and three represent service-based firms. All businesses are run by individual(s) with immigrant background. All firms are made anonymous and named after their respective character. The scienceand technology-based firms are called "Glass", "Digital", "Smart Cards" and "TV Advertising”. The service-based firms are called "Health”, "Food” and “Translations”.

Methods used include different qualitatively inspired techniques, such as ethnographic approaches and observations. Meetings, conversations, interviews and discussions with individual(s) involved are the main sources of information. Further, experts in different areas and people with insights in each of these firms were also interviewed. This is a means of increasing the credibility of the cases and the certainty that we do not just take the stories of the individual(s) involved for granted without checking them with people without a stake in the firms. Thus, all cases include inputs from at least two people whereof one external - in order to get a more representative and adequate view of each firm. Altogether, we spoke to nine experts, and we also had discussions with them about the general climate for businesses in Kista and Sweden. Their experiences and insights provided valuable input in the process of trying to understand the role of support systems for small firms in Sweden today. For further details on data gathering, see Dalhammar (2004).

We use the dimensions in the conceptual framework - as presented in part 4 - as a guideline to construct the empirical cases in the next section and to interpret and analyse

\footnotetext{
${ }^{7}$ Source: http://www.kista.com/artikel/95/001004/se.

${ }^{8}$ Kista Science City is an image concept but also connected to a definable geographical area which includes other parts of Stockholm municipality as well as parts of other municipalities in the greater Stockholm area. Apart from Kista, Southern Järva ('Södra Järva') and parts of the municipalities Sollentuna, Järfälla and Sundbyberg are included in the Kista Science City concept. Around 120000 people live in the area defined as Kista Science City, more than 6000 companies are established there (http://www.kista.com/foretagsregister.html?soktyp=f\&mid=007004), and about 65000 people work in this region (http://www.kista.com/artikel/105/014009/se). Albeit Kista Science City is a bigger concept than Kista, the Kista district is the focus in this thesis.

${ }^{9}$ Source: Website of the Swedish public television news program, http://www.svt.se/nyheter.
} 
these texts in part 6. Using the conceptual framework is a means of introducing a more general approach to entrepreneurship studies for studying the sub-field of immigrant and ethnic entrepreneurship. The only thing the firms in our study have in common is that they involve people with immigrant backgrounds. While it is not our intention to predestine and predetermine these firms, how ethnic resources contribute to the resource acquisition of the firms is a question that will be dealt with empirically.

\subsection{Firms}

The firms are studied from the perspective of what sources they use and utilise for their resource acquisition. The presentations are written from the specific process that each firm goes through and in each case we provide examples of how ethnic resources have or have not been crucial in the firms' resource acquisition.

\subsubsection{High tech firms}

\section{Glass (developing new glass material)}

Glass is a research and development firm based on a newly discovered and patented advanced glass material with commercially interesting properties. The entrepreneurial team consists of three men, all originating from Iran: two childhood friends - S and A both around 30 years old, and S's father N. S is the inventor of the material and A works with the market. S and A own $50 \%$ of the shares each and $\mathrm{N}$ functions as a consultant since he has long business experience in industries relevant for product applications based on the material.

A has actively sought access to settings where they are able to find the specific resources they need. In 2003, Glass was accepted to an incubator program in Kista Science City. A's contact with this organisation was based on recommendations from other people at other business support organisations and the team considered several alternatives before they decided to proceed and join this particular setting. They stayed there for six months, but then they moved to a new location in central Stockholm. A talks positively about their new business advisor and the person they work closest to in their new location. "We need him right now", A says. "He can help us since he understands the industry and applications we're involved in. He's good at patents!” And their new advisor is positive: "Glass follows a development that's very good!"

The team also has contacted top people within the Swedish industry, and according to A this makes it easier to find financial capital. These people act like "door openers" and add to the legitimacy of their business idea. "We've got many influential people to support our firm, both as references but also as board members", A says. "We think it's important to have these people supporting us if we want to get credibility for our business!" And Glass has managed to get the money they need for the complicated and complex patent process of the glass material. Further, they have gained legitimacy for their business idea in that they won first prize in Vinnova's Vinn Nu contest.

A says that he and S always have been entrepreneurially driven and that this partly can be referred to their cultural background. He says that the Iranian culture is "elitist and competitive". "The families helped us when the corporation was founded. These were no big amounts - just to cover the corporate capital requirement.” However, A states that the success of the business does not depend on ethnic resources of any kind since their ethnic network cannot provide them with the resources they need. "That's not central in this business. I actually haven’t thought much about it!” And their former business coach at 
the incubator program in Kista Science City concludes: "On the whole, Glass was like working with any firm. I can't say that it was particularly different because they have Iranian origin.”

\section{Digital (digitally monitoring remote systems)}

Digital develops new digital technology for monitoring, regulating and controlling remote systems. At the moment, the firm is focused on the process industry, where the technology can be used to control remote machines and robots. However, the technology is very much adapted for the telecom industry and efforts will be put there in the future as well. The founding team consists of two people who each own $50 \%$ of the shares: S, a 36-year-old man originating from Iran and the inventor of the technology on which the firm is based, works with technology and product development. $\mathrm{H}$ is a 43-year-old native Swedish woman who works with the market side.

In S's family, many people have had their own businesses. He has also run two firms before. "It's completely different to work in this type of business and industry compared to the firms I've run before”, S says. He says it involves more long-term partnerships. "This is the kind of business I've always dreamed of! I want to have stable relations to a couple of partners and work closely with them to develop products in various projects." Despite the fact that his family has strong entrepreneurial focus, he has not got any help from his family with Digital. "I haven't needed it!" There are also traditions of business activities in H's family, and she previously ran a firm together with her husband. However, she carefully explains that she draws a straight line between business and friendship and has not involved her family in this business.

There are people helping $S$ with the technical development of the digital platform. These are friends of his with Iranian background. They have agreed to sign a contract where it says that they will get paid if the firm becomes profitable. "They do this on their free time since they think it's fun to work with this product. They enjoy technical solutions", $\mathrm{S}$ says. Still, $\mathrm{S}$ utilises this cheap ethnic labour since the financial situation is tough. But generally, both $\mathrm{S}$ and $\mathrm{H}$ state that S's immigrant background has not affected the activities of the firm. "I haven't thought of it before", S states when asked about it. But both $\mathrm{H}$ and S state that they want diversity in terms of people. "We need both the right competences and the right people”, S asserts.

Digital has taken measures to find resources connected to their specific business idea. The firm was also accepted to the same incubator program as Glass in Kista Science City. S first contacted Stockholm Innovation as a matter of getting assistance concerning where to go with his idea. "The person I contacted there was a person I knew from before. She told me about the program in Kista." "I know how to write applications", $\mathrm{H}$ fills in. "We had about 4-5 meetings with people there. It was a long process and it was far from certain that we would get accepted." However, they eventually got in. "We believed in the idea and the people", their business coach in the program says. "It's all about legitimacy and legitimacy opens the door to new valuable contacts and relations", $\mathrm{H}$ says. "When we've talked to other actors and potential partners, I've noticed that it is positive to mention that we sit in this environment!”

"Digital has had a very fast progress", H says. One month after they entered the incubator program, the joint-stock company was founded. One month later, they received contribution from ALMI to develop their innovation. One month after that they received 
first prize in Vinnovs's Vinn $\mathrm{Nu}$ contest. And about six months after the firm was founded, they had a prototype ready for demonstration. Still, the industry is demanding. Their business coach at the program says: "What Digital needs is knowledge about and within the process industry. Further, they need more developers for faster technological progress. There are people with the right competences, but since they don't have money they can't pay them for their work. This means they are forced to use solutions like they do right now - that S's Iranian friends work here for free with the development of the platform.”

\section{Smart Cards (developing smart card chips)}

Smart Cards is a firm engaged in the smart card industry and develops the next generation of new smart card chips. It is organised as a corporation. The aim is to build and maintain relationships with smart card vendors globally. The idea is to improve and increase the performance of their cards with more efficient tailor-made hardware solutions on the chip. O, a 41-year-old man originating from Iran, is the founder and owner of the firm. He mainly works with technology and product development. O owns all the shares and runs the firm together with an assistant, L, a 60-year-old native Swedish man, who mainly handles business contacts.

In Iran, $\mathrm{O}$ ran a firm together with his father and when his father died, $\mathrm{O}$ took over the firm. L has previously worked with sales, translation and education. Further, he has helped one friend and his former wife to build up two separate firms. Right now L does not get any compensation for his work. He does unpaid work, so to say. L assures that $\mathrm{O}$ is Smart Cards. “I just help him out. I do this because I think it's fun”, he says.

In order to finance the expensive product development, $\mathrm{O}$ has invested a large sum of his own money, including money he borrowed from family and friends. But he has also succeeded in finding other sources of financing. "When I presented all my work for SIC ('Stiftelsen InnovationsCentrum'), they gave me money after just a few days, a loan of 400000 SEK. They were impressed by that I had already done market analyses and that the idea was ready to go.” Altogether, the firm has raised about 2 Million SEK from different institutions (SIC, ALMI, Vinnova and NUTEK). "It's different to start a firm like this compared to other kinds of businesses”, O says. “The money I've raised doesn't cover much and the applications for patents consume much of it. This means I generally can't pay potential partners for their work. No one works for free - one has to create incentives! One way is to reward them later if my firm succeeds." They have a business contact and advisor at ALMI who says: "Today, many immigrants are dependent on that family and relatives help them financially. In mature industries, families and friends often have the ability to help, but in high tech the same possibilities don't exist.”

The team experiences difficulties to have an income while developing a firm like this. According to L, this is the major problem. "Financing, personnel resources - although this is not up for discussion yet - and to find the right people to work with is crucial for success." Their contacts and network relations symbolise a way of solving problems. "Networking is problem-solving - that's what it is. This is true not just for us but for all developing firms. But it has to do with personal engagement, not just formal contacts. In these contexts people are incredibly important! Formal competence, yes, but it also has to do with competence in relations. The people Smart Cards works with represent such competence", L asserts. O explains there are 6-10 people in a network that help him concerning specific matters. "I buy the competence I don't have”, he says. Further, O 
says that one has to be careful: "There are many charlatans in this industry. Many firms try to look much better than they really are.”

Smart Cards applied for a place in an incubator program in Kista but they did not get in. The project leader at that support organisation says: "They came to us and applied for a coaching relation but we rejected their application. We didn't believe in their business idea! We had doubts along a few of the dimensions we use for evaluating the innovations. This has to do with competences, resources and focus of the venture." However, Smart Cards has managed to find an office in facilities run by this organisation. According to $\mathrm{O}$, this setting still has been helpful for Smart Cards since it gives credibility and provides access to a network of potential partners and customers. "Financing and customer and partner contacts have to do with credibility and this setting provides trustworthiness. This is even more important for me as an immigrant entrepreneur, since I may not have the same contact network as native Swedes.”

L says that an EU project with a number of partners is about to be launched. " $O$ is the originator of this project. Some parties involved in this partnership network are quite big." Further, although $\mathrm{O}$ is a bit secretive about the future since no deals are official yet, he tells me he has "...discussions with business angels and venture capitalists right now", so he thinks the future looks prosperous.

\section{TV Advertising (developing systems for targeted advertising solutions)}

TV Advertising is a firm directed towards the television and broadcasting market. The product is a combination of a chip and a management system. The firm focuses on digital TV and its domain is in the general area of 'targeted advertising solutions'. $\mathrm{K}$ - the founder of the firm - originates from Iran and is in his mid-thirties. He owns all the shares in the firm. Until now, he has run the firm completely on his own from his home in Kista.

$\mathrm{K}$ has previously run businesses and still has a firm working with photography and editing for the television industry. In order to support himself, he does various work. "I do extra work with completely different things. I have many jobs on the side! This is the way I support myself." His business activities do not reflect a heritage of any kind. "We have no tradition of business ownership or entrepreneurship in my family. This is more a personal thing. I have a personal motivation towards entrepreneurship.”

$\mathrm{K}$ has acquired much money from family and friends to apply for international patents. "In Iran people don't make the same distinction between my money and your money as in Sweden. When it comes to your parents you'll inherit their money anyway sooner or later." When borrowing money, he sometimes is obliged to listen to opinions from family and friends, but he solves that by "choosing what opinions I should listen to". And despite the fact that friends would provide cheap or even free help, he refuses such help. "I don't want to work with friends!" he says. He has bad experiences from this, where it has even led to losing friendship because they have not been able to separate work from pleasure.

Apart from the money he borrowed from family and friends, $\mathrm{K}$ has got a small loan from SIC ('Stiftelsen InnovationsCentrum'). $\mathrm{K}$ has talked to several actors in the business support system, both public and private who has introduced him to further contacts. "I contacted a few patent bureaus and a couple of engineers at another firm helped me 
develop the idea technically." Still, he needs much seed capital in order to develop and realise his idea. "I have estimations indicating that I need about 10-20 million SEK to develop all the solutions for the complete solution.” K currently looks for a setting where he can find the assistance and the contacts he needs to develop his innovation. He has taken the start-up program offered by a business support system in Kista - the first step in their support program - and he has applied for a place in the next step in this program where he would get access to an office space in their business incubator. "They can give me contacts and assistance. They provide credibility and legitimacy! The economic relation is less important. I can sit somewhere else and I don't save that much money to sit there.”

$\mathrm{K}$ talks about the specific condition in the high tech industries. "If you start a company too early you won't have the persistence to be in business until the market is ready and you can commercialise the idea", he says. "If a native Swede would go to partners and investors and present the idea I have it would be much easier for him or her! Immigrants have small and limited networks. Native Swedes have easier to access important contacts than immigrants, because they commonly know someone who knows someone etc.” And he says he gets treated differently compared to native Swedish people. "When I talk to someone, first of all I'm foreign, then entrepreneur. A Svensson is first of all an entrepreneur!”

"Personally, I have experienced some difficulties with the language, but I know that others have had much worse problems. You have to know either Swedish or English if you want to talk to people. Otherwise you have problems." Here, a native Swedish partner would help, K says. "Sometimes, it's good to have a person that takes care of external contacts - one that masters the language. Today, I don't have such a contact, and I don't need it right now, but it will be needed in the near future." And his contact at the incubator program confirms that $\mathrm{K}$ needs partners in TV Advertising: "K runs this on his own and that's one thing we generally don't recommend."

\subsubsection{Service-based firms}

\section{Health (health care store)}

Health's business idea is to sell health care products and provide massage and spa services to private and corporate customers. The turnover from selling products in the store and giving massage and treatments go hand in hand. However, a majority of the revenue comes from providing massage and spa treatments. The founding team consists of two spouses. R, a 48-year old woman who originates from Iran, and S a 38-year old man originally from Bangladesh. $\mathrm{R}$ is officially the firm owner (sole proprietor) and the one who leads the firm, but they work a lot together and in many ways drive the firm as a team.

$\mathrm{R}$ and $\mathrm{S}$ do not have traditions of business activities in their families and they have not run businesses before. However, they both have previous experiences from the healthcare sector. "The initial plan was to have people employed, but we couldn't afford that. Instead, we have independent contractors. They provide different treatments and services to customers. It's not profitable for these people to rent a space here so the deal is that we share their revenues 50-50. We're all part of a team!”, R concludes. Around five people work at Health on a somewhat regular basis. 
"The big problems are money and contacts”, both R and S state. R says that they have problems for two reasons - the disadvantage of being an immigrant and starting a business. "We don't have good contacts. I mean contacts with authorities. When you're an immigrant you don't know where to turn." $\mathrm{R}$ and $\mathrm{S}$ applied for business loans, but both ALMI and the bank turned their idea down. "They said they didn't believe in the business idea”, R says. Since they did not get any support, they have mainly financed the firm with their own money. They have also borrowed from family and friends in their home countries. They have a contact at the Kista administration who says: " $R$ is interesting, because she managed to start her firm without any support from the surrounding community. She hasn't got any money from here (e.g. banks or public institutions - author's note) but had to bring these from her home country.”

A masseur who works in the store says that this is a tough industry for a new business. "It takes one year - then people know where you are. After two years, people know who you are.” He adds: the tragic thing in this business - and then I talk about small private firms - is: 'If 10 satisfied customers leave this store, we get one additional customer. If one dissatisfied customer leaves this store, 10 customers disappear!’”

The firm has plans for expansion. They have got permission to have an outdoor café during the summer. "We'll serve sandwiches and hot and cold drinks. We think this is a way for us to attract customers. It seems like people are afraid to enter the store. They might think that it costs 2000-3000 SEK to go in and buy something, I don't know. With the outdoor café we believe it will feel more natural for customers to come here.”

\section{Food (catering firm with exotic food)}

Food is a catering firm located close to Kista center. It serves food with an exotic touch, such as African buffets. Catering arrangements is the main activity, but they also serve lunches, salads, main courses and desserts. Z, a 48-year-old woman originating from Iran, is the leader and runs the firm, although it still is organised as an economic association. At present, the firm employs 4 people, whereof $\mathrm{Z}$ and another woman, $\mathrm{A}$, are full-time and two, Za and E, are part-time workers. Further, Z's daughter and son occasionally help out in the firm. Besides, $\mathrm{Z}$ brings in people she knows when they have higher workloads or big orders, for example. These people are generally Iranians. "It's easier to come in contact with people I know, personally or through contacts." This means the chance is greater that Iranians and other immigrants are included.

From the beginning, this was a cooperative project initiated by the Kista administration. Their contact there says: "It was targeted at unemployed immigrant women. Twelve women, all registered at the unemployment office in Kista, were recruited.” People quickly started to leave and $\mathrm{Z}$ took the role as the leader of the business. Although there naturally is an ethnic market for this food, most customers are native Swedish, since these are the ones most interested in the food. "This food is more exotic to them. For us, this food is normal. We cook it at home, so why couldn't we do that here as well!? The people that come from other countries already know how to cook this food!” Z says: "Business clients are the most profitable ones, but all customers are important!"

The firm still gets help from the Kista administration and their contact there actually is a board member. This contact provides much help when it comes to external relations. 
Their contact agrees that Food has received much support and informal help as a consequence of personal relations. "Formal assignments were developed into informal over time", their contact says. Further, she states that in order to be successful, immigrant enterprises need mentors they can call when having questions about various issues. Further, network relations are important. "They need a network with different parties. I'm a link into the Swedish society, and they need people in their networks with different backgrounds."

$\mathrm{Z}$ has utilised contacts media to promote the business. Food has been mentioned in papers and magazines at several occasions. "This has definitely been good for us!", she states. She keeps a big amount of articles from various newspapers in her office. It is a big pile of documents. "Apart from this I've also been interviewed in the radio about our business a couple of times." $\mathrm{Z}$ says that the reason for this attention is that they have stayed in business for so long, and at the same time people in the Kista administration have supported and promoted Food at different occasions. "The writings in the newspapers and the positive marketing we've got are very helpful! After the article in Svenska Dagbladet ${ }^{10}$ we've got many orders. We're also represented in various guides on the Internet. We're visible - that's good marketing!”

$\mathrm{Z}$ has plans for expansion. She hopes the firm can close deals with one big public actor. "When they have seminars and conferences, we will deliver food to them." Further, the firm will probably go from economic association to a corporation quite soon. "Many of the former people who worked here from the beginning want to buy shares, so it shouldn't be a problem to find enough capital”, Z says.

\section{Translations (translation and interpretation broker service)}

Translations is a broker service firm that mainly offers interpretation and translation services to clients. The business concentrates on big public customers, and focuses on long-term contracts. R, a 46-year-old woman originating from Turkey (Kurdistan), leads the firm and mainly deals with business contacts. She also owns all the shares in this firm. Apart from R, four people - G, K, H and T - are employed in the firm. They all work with practical day-to-day issues concerning the interpretation broker service.

R speaks both Kurdish and Turkish apart from Swedish. "Before I started my own firm I worked extra for different translator firms when possible. This was the only industry where I could start a business, so it was an easy choice to start within interpretation and translation. Naturally, I gained from my previous experiences in this area.” R says the success of the firm is due to her own work and she had no help from family or friends. Still, she received much assistance when the firm was started. She was accepted to a start-up program in her neighbourhood and that was crucial for founding the firm: "But the decisive thing was the project to which I was accepted! If not for that, I probably would have studied instead." The person in charge of the project at the local administration explains that the project was a trans-national EU project. "I'm definitely proud of R!", he says. "She and another guy are the ones that have done well."

R says: "I had big support in the project: office, copier, furniture and telephone. I had no support from my family and no business experience. I didn't ask anyone, but made the decision myself to start the business!” Further, R makes clear she started with zero

${ }^{10}$ A widely read national Swedish newspaper. 
financing. "I got business start-up subsidies ('starta eget bidrag') for one year that I was allowed to keep even though I had incomes from the firm.”

"During the first years, there was much marketing and hardly any assignments. I worked much with contacts to media. TV, papers, weekly and monthly magazines etc. Sometimes, the facts weren't correct, but it's important to be seen! Today, there are some people that contact me and want to talk to me about my business. These are researchers, students and different kinds of organisations. I don't have time to meet them all!” R has a contact at the Kista administration and he likes R's initiative: " $\mathrm{R}$ has proved that she's not dependent on anyone to succeed. I like her because she's a strong woman, and being a woman is a handicap in the Swedish society today."

A majority of the people that work in R's firm at present are immigrants. "That's a coincidence!", she tells me. It's just happened that I have taken in people with immigrant background. I've had many people on vocational training, at least 10 . These vocational training places are a distributed by the unemployment agency. Many of them have been for a limited time, normally 3-6 months. After that, some of them have been offered jobs here."

R says she has big plans for the future. "I want this to become big. I want to be able to breathe and not having this hanging over me every day. As it is now, I have no time for myself. I don't have time to go out and meet my friends - the social life is neglected. I work 55-60 hours/week. I bring work home with me, mainly during weekends; invoices, wages. I'm the only one who can do certain jobs. I have an accountant and bookkeeping consultant that does some of this work, but I do a lot myself!” And the way to become bigger is spelled volume. "We need bigger volumes - that's where our competitors have an advantage! We get bigger volumes by getting big long-term contracts with public clients. Then I could hire more people and work less myself.”

\subsection{Resource acquisition and ethnic resources}

In the table below we present an overview of the utilisation of ethnic resources among the firms.

\begin{tabular}{|l|l|l|l|l|l|}
\hline & $\begin{array}{l}\text { Financial } \\
\text { capital }\end{array}$ & $\begin{array}{l}\text { Organisational } \\
\text { capital }\end{array}$ & $\begin{array}{l}\text { Human } \\
\text { capital }\end{array}$ & $\begin{array}{l}\text { Social } \\
\text { capital }\end{array}$ & $\begin{array}{l}\text { Ethnic } \\
\text { market }\end{array}$ \\
\hline Glass & $\mathrm{X}$ & & $\mathrm{X}$ & & \\
\hline Digital & & $\mathrm{X}$ & $\mathrm{X}$ & & \\
\hline Smart Cards & $\mathrm{X}$ & & $\mathrm{X}$ & & \\
\hline TV Advertising & $\mathrm{X}$ & & & & \\
\hline Health & $\mathrm{X}$ & & & & \\
\hline Food & $\mathrm{X}$ & $\mathrm{X}$ & & $\mathrm{X}$ & $\mathrm{X}$ \\
\hline Translations & & & $\mathrm{X}$ & & \\
\hline
\end{tabular}

Table 1: Utilisation of ethnically derived resources of the firms in this study.

The limited number of cases could explain the relative little utilisation of social capital and focus on ethnic markets among the firms. If there had been restaurants and grocery stores, these firms would possibly have shown different results. Still, with this limited number of cases, all types of important ethnic resources are represented. This indicates that these variables are useful as a means of understanding the nature of ethnic resources. 
Utilising ethnic resources generally means utilising ethnicity as a resource. However, utilising ethnicity as a resource does not always mean that the individual(s) involved use ethnic sources for their resource acquisitions efforts. They may also utilise that they are ethnic minority, e.g. that they can get certain subsidies (like 'starta eget-bidrag, ${ }^{11}$ ) or gain admission to business or incubator programs targeted at immigrants and/or ethnic minorities. This is the case for $\mathrm{R}$ in Translations. Translations's case provides a concrete example where ethnic minority background may have an important impact on the resource acquisition process of immigrant and ethnic businesses. $\mathrm{R}$ did not utilise ethnic resources, but her ethnicity facilitated her acceptance to the business support program. This is actually the opposite of community involvement. The point we want to emphasise is that utilising ethnic resources and ethnicity as a resource does not necessarily mean the same thing and that there are pros and cons with both.

\section{Interpretation and Analysis}

We go through the dimensions in the conceptual framework and through concrete examples from the cases we present how ethnic resources and ethnicity as a resource are used to acquire crucial resources for the firms. Since this is an exploratory study whose goal is to generate new theoretical assumptions for further research, we do not interpret and analyse each firm separately. Instead, we look for patterns in resource acquisition of the firms in relation to their business logics.

\subsection{Organisation - type of industry or firm}

Using Samuelsson's (2001) definitions, all four high tech firms (Glass, Digital, Smart Cards and TV Advertising) in one sense or another are engaged in creating new market transactions, thus exploiting innovative venture opportunities. In Glass, it is the glass material, which is expressed as an important breakthrough. Digital's new digital platform is described as a 'shift in technology'. Smart Cards's smart card chips 'enables handling of more applications' and 'improves overall performance'. And TV Advertising's broadcast solution is a means of using digital technology in a new way. In contrast, the service-based firms (Health, Food and Translations) are more oriented toward exploitation of imitative venture opportunities.

In the cases there are several examples where sources for acquiring resources are affected by industry and business logics. Even though ethnicity - as in terms of country of origin and sense of 'immigrant belonging' - is not unimportant in the high tech firms, it is not an issue concerning the acquisition of crucial resources. Instead, technology and characteristics specific for the individual ventures are brought up in high tech cases. Individual(s) involved in the ventures as well as external advisors and business coaches give examples of conditions quite specific for firms in the high tech sector. The cases show that the specific resources needed (as in large sums of financial capital or specific vocational skills) cannot be acquired utilising ethnic resources.

For the service-based firms, our analysis seems to reveal that ethnic resources contribute to a higher degree to the acquisition of crucial resources. Translations's business is based on R's ethnic resources of language and her knowledge about other cultures is also helpful. Food's very business idea reveals that the firm draws on specific ethnic

\footnotetext{
${ }^{11}$ This is a subsidy that people who have been unemployed for a longer period of time can get in order to start up their own firms. In Sweden, it is generally easier to get this source of financing if you are an immigrant and/or belong to an ethnic minority.
} 
knowledge about cooking and serving exotic food. Health's health care store draws strongly on ethnic resources to acquire financial capital since - in addition to the founders' own money - additional financial resources for the start-up were borrowed from family and friends. For a science- and technology-based firm, it is generally not possible to acquire neither sufficient financial capital nor e.g. organisational capital (mainly labour) by merely utilising ethnic relations. Essentially, in our study the division between innovative and imitative ventures equates the division between high tech/science- and technology-based and service-based firms. This suggests that ethnic sources for resource acquisition are more important for the service-based firms.

\subsection{Individuals - Proactive behaviour}

Looking at the second dimension - the individual(s) driving the ventures - there are examples of different attitudes toward action and risk, issues that do not depend on business logics, i.e. type of industry or firm. In Glass's case, the people involved show that they constantly have looked for opportunities to develop the business, which has resulted in choices to move to different settings. Digital utilised contacts to enter a business support system and the founders quickly focused on finishing the prototype and bringing it to the market. And both Glass and Digital handed in applications and received prizes in organised business contests.

$\mathrm{Z}$ at Food also exhibits proactive behaviour, in the sense that she has utilised contacts to media to promote the firm. Further, she has managed to get continued support long after the termination of the initial cooperative project. $\mathrm{R}$ at Translations managed to access a supportive project aimed at immigrant businesspeople that was crucial for the start-up. $\mathrm{R}$ also utilised contacts to media to promote the business. Further, she is involved in business societies in the borough where she lives. K at TV Advertising has contacted several actors, both in Sweden and internationally, in order to find a setting where he can acquire resources and develop his business solution. $\mathrm{O}$ at Smart Cards has gone through several parties in order to find an adequate setting and his networking activities have led to involvement in an EU project with big potential. In Health's case, the founders exhibit behaviours somewhere in between. They have tried to access some settings for support, but do not seem to have utilised all possibilities at hand. Although there are no absolute borders regarding definitions in this matter, in our study there is no example of a firm where individual(s) involved clearly show reactive behaviour.

\subsection{Environment - Interactions with actors in the business support system}

Not surprisingly, business support aspects have shown to have crucial impact on the progress and development for all firms in our study. Translations is a good example of this, even though it in fact represents a case where the presentation is rather ambiguous. Her case is the following: although R puts herself and her own work in focus and regard this to be the important factors for the creation and development of the firm, the project she was accepted to and the support she got have been crucial for the start-up and development of her business. If not for this support, the firm would not have come into existence at all and $\mathrm{R}$ would have done something else. In fact, her strivings show how proactive behaviour makes it possible to utilise ethnicity as a resource. And Translations is not alone in this study. Food has a similar story, where the initial cooperative project received and the firm still receives much support, not the least by the Kista administration. In contrast to these two firms - as well as to Glass and Digital - Smart Cards, TV Advertising and Health represent three voices that have experienced greater difficulties in gaining adequate support in their interactions with the surroundings. They 
clearly express the need for better assistance. However, there seem to be fewer alternatives for Health than the other two.

\subsection{Summary of findings}

The interpretations and analyses of the cases point at differences regarding the resource acquisition between the high tech and the service-based firms. These differences can be referred to the organisational perspective on type of industry or firm, i.e. industry and business logics. However, the aspects of proactive behaviour and the interactions with actors in the business support system are not related to type of industry or firm per se. And these aspects also affect the utilisation of ethnic resources.

Type of industry or firm affect what resources are available in the environment and what resources can be acquired using ethnic sources and ethnicity as a resource. Proactivity reflects the behaviour to act toward and mobilise resources, whether ethnic resources or 'mainstream' resources in the general business support system. And the interactive dimension reflects the activity to acquire resources through business actors in the surroundings, which is closely related to proactive behaviour. Thus, these three dimensions affect and interact with each other. Our elaboration on Gartner's (1985) framework assists in understanding and generating knowledge about resource acquisition of immigrant and ethnic firms. As a consequence, this conceptual and methodological tool justifies its use in this study - and in future studies as well, we believe.

\section{Conclusions}

In this paper, we derive from the assumption that type of industry or firm affects the utilisation of ethnic resources and thereby the importance of ethnic background for immigrant and ethnic businesses. As discussed in part 6, type of industry or firm is important, but other aspects - the degree of proactive behaviour of the individual(s) involved and interaction with actors in the business support system - also affect the firms' resource acquisition. Based on our interpretations and analyses, in Model 1 we present different ways to view the influence of ethnic background for the firms in our study. First, we introduce a model that combines the individual and organisational dimensions: type of industry or firm and proactive behaviour of the individual(s) involved. Thereafter, we continue by adding the environmental dimension on interactions with actors in the business support system.

\begin{tabular}{|c|c|c|}
\hline \multirow[b]{2}{*}{$\begin{array}{l}\text { Proactive } \\
\text { behaviour }\end{array}$} & $\begin{array}{l}\text { Service-based } \\
\text { firms }\end{array}$ & $\begin{array}{l}\text { Science- and } \\
\text { Technology-based } \\
\text { firms }\end{array}$ \\
\hline & $\begin{array}{l}\text { Translations } \\
\text { Food } \\
\text { Asset }\end{array}$ & $\begin{array}{l}\text { Digital } \\
\text { Glass } \\
\text { Non-issue }\end{array}$ \\
\hline $\begin{array}{l}\text { Reactive } \\
\text { behaviour }\end{array}$ & & Barrier \\
\hline \multicolumn{3}{|c|}{$\begin{array}{l}\text { Model 1. The influence of ethnic background for the firms in our } \\
\text { study in relation to type of industry or firm and proactive behaviour } \\
\text { of the individual(s) involved }\end{array}$} \\
\hline
\end{tabular}


Model 1 above addresses the question how ethnic background affects new venture creation in science- and technology-based firms and service-based immigrant firms. This model mainly represents the experiences of key people - as in founders or founding teams - complemented with insights from experts such as mentors and business advisors

The model proposes that in high tech ventures where individual(s) involved exhibit proactive behaviour, ethnic background is of minor importance and becomes a non-issue (Glass and Digital). In the service-based ventures where individual(s) involved exhibit proactive behaviour, ethnic background becomes an asset, mainly in the sense that deriving on ethnic resources can provide resources that may lead to a competitive advantage. Utilising ethnic resources and ethnicity as a resource often go hand in hand. But as discussed before, this is not the case with Translations, where the utilisation of ethnicity as a resource is not connected to utilisation of ethnic resources. On the other hand, Food represents a business that recognises the value of ethnic resources and utilises them. Because of the uncertainty connected to the other three businesses (Health, Smart Cards and TV Advertising), these are placed in-between possible fields in the model below.

In order to understand the situation for these three firms, one more dimension needs to be added. This refers to interactions with actors in the business support system. Unlike the other four firms (Glass, Digital, Food and Translations), Smart Cards, TV Advertising and Health have not gained necessary support in their interactions with the environment. Concerning these three uncertain firms, the individual(s) involved exhibit (at least partly) examples of proactive behaviour. Above all $\mathrm{O}$ at Smart Cards and K at TV Advertising continuously seek new opportunities and look for help in the support system in order to develop their business ideas. However, they still feel they lack sufficient support. The fact that they fall under the category of ethnic minority background as a potential barrier or excuse in the model above, rather reflects problems in relation to the support system than reactive behaviour. Thus, this reflects a shortage of resources. These concern social and cultural capital aspects, which in turn lead to a shortage of other types of resources, mainly financial capital. Although both O (Smart Cards) and K (TV Advertising) state they have not been directly discriminated, with their own words they say they lack 'knowledge of the codes' $(\mathrm{O})$ and 'language' $(\mathrm{K})$. But these problems cannot merely be referred to them as individuals, but to relations to the support system around them, including a number of actors. In the same manner as these firms are expected to adjust to the nature of support system, one can argue that the support system ought to adjust to the competences of the firms. In other words, the environment does not address their needs in acquiring new competences and resources to their firms.

The actors in the support system seem to agree. Today, there exists no support organisation comprehensive enough to address specific needs for different venture opportunities. NyföretagarCentrum offers more of general help and according to Smart Cards's contact at ALMI, this support organisation does not have enough resources on their own to help firms the way they want to ${ }^{12}$. This implies that there may be shortages in the support system contributing to the difficulties firms in this study face. And several people we have interviewed - both businesspeople and experts - express that an immigrant business needs more specific support due to lack of knowledge about how to start and run businesses in Sweden. Gaining confirmation and legitimacy therefore seems

${ }^{12}$ Expressed during a phone conversation 040130. 
to be even more important for immigrant entrepreneurs in comparison to 'mainstream' entrepreneurs. This discussion about complexity in relations with actors in the surroundings supports Gartner's (1985) ideas that there is a range of individual needs to address in supportive actions. It also confirms Van de Ven's (1993) view that the entrepreneurial process is a collective effort that demands actions during a long period from many parties, both within the industry and the public sector.

\section{Implications and discussion}

The results of the research presented in this paper have implications for different kinds of stakeholders.

\subsection{Academics}

This study shows that structural and cultural theories both play important roles when researching immigrant and ethnic entrepreneurship from a resource perspective. The field of immigrant and ethnic entrepreneurship should not be treated or regarded as homogeneous. Immigrant entrepreneurship could be used as the overall concept in order to grasp business activities by individuals who have immigrant backgrounds, whereas the concept of ethnic entrepreneurship could be used when the acquisition of ethnic resources and ethnicity as a resource are studied. However, every study should be clear about what aspects of immigrant or ethnic entrepreneurship that are studied.

\subsection{Practitioners}

Business advisors should note the importance of encouraging proactive behaviour of immigrant and ethnic entrepreneurs. Further, they should encourage their business clients to find creative ways for resource acquisition. This includes ethnic resources, i.e. resources that the advisors themselves usually cannot provide or mediate. They should also make their clients aware of the importance of assessing ethnic sources for resource acquisition, since there are costs involved in such operations, not the least social costs.

From a practical perspective, this means that supportive actions must address different needs depending on type of industry or firm and to what degree the individual(s) involved exerts proactive or reactive behaviour. The degree of confirmation and legitimacy, thus recognition, from actors in the environment are crucial for all businesses, but maybe even more crucial for immigrant and ethnic businesses, as they often lack sufficient social capital on their own.

\subsection{Public policy}

Policy makers should ask themselves a number of important questions. Are there certain business activities they want to encourage, e.g. high tech immigrant/ethnic entrepreneurship? And are there certain measures that should be taken to get higher levels of business activities in these sectors? These questions deal with views on ethnicity and ethnic resources. As previously discussed, ethnic resources could be both a blessing and a nightmare, depending on the relative competitive advantage or disadvantage they provide.

At the moment, those few ethnic minority businesses in Kista are just fragmented voices. But in a not too distant future, they may be part of a whole ethnic high tech cluster and society. If this ethnic high tech entrepreneurship will be similar or different to what it looks like in Saxenian's (2001) description of Silicon Valley is an open matter. However, 
there is a great likelihood that there will be spillover effects to the rest of Stockholm and the Greater Stockholm region. Then we will experience developments that affect economic activity as well as matters of integration. This is why the high tech industry is so interesting and important in relation to other industries where there often is an overestablishment of ethnic firms: it creates possibilities to turn ethnicity (and the view on ethnicity) into a potential resource instead of a burden.

\subsection{Final reflections}

Our study shows that there is representation among immigrant/ethnic businesses in Sweden today for a more complex picture than the conform view on immigrant and ethnic entrepreneurship commonly presented. Both the conceptual framework and Model 1 are contributions of this paper. However, since this is an exploratory study, it is up to future research to further investigate the appropriateness of these findings. While it is likely to assume that the topic of immigrant and ethnic entrepreneurship will be highly relevant in the future as well, it is our belief that our work can be further elaborated and researched. We hope that future studies will further contribute to this field of research in similar or different contexts than Kista. One example would be to compare immigrant and non-immigrant businesses in the same type of industry, like science- and technologybased firms, engaged in similar or different contexts. Further, identity of entrepreneurs is another interesting dimension that some researchers previously have studied (Fletcher, 2003; Hytti, 2003). This dimension is interesting in relation to immigrant and ethnic entrepreneurship, since it is likely that business identities of individual(s) involved affect resource acquisition of their firms. 


\section{References}

Abbasian, Saeid (2003). Integration på egen hand - En studie av invandrade kvinnoföretagare i Sverige, Uppsala universitet, Geografiska regionstudier nr 52, Eklundshofs Grafiska. Doctoral dissertation, Uppsala University Sweden.

Aldrich, Howard E. (1999). Organizations evolving, SAGE Publications.

Alvarez, Shannon and Busenitz, Lowell B. (2001), 'The entrepreneurship of resourcebased theory’, Journal of Management 27, pp. 755-775.

Ardichivili, A., Cardozo, R. and Sourav, R. (2003). 'A Theory of Entrepreneurial Opportunity Identification and Development', Journal of Business Venturing, 18, pp. 105-123.

Barney, Jay B. (1991), 'Firm resources and sustained competitive advantage', Journal of Management 17 (1), pp. 99-120.

Bateman, T. S. and Crant, J. M. (1993), The proactive component of organizational behavior: A measure and correlates. Journal of Organizational Behavior, 14, pp. 103118.

Becherer, R. C. and Maurer, J.G. (1999), The proactive personality disposition and entrepreneurial behavior among small company presidents, Journal of Small Business Management, 37 (1), pp. 28-36.

Bozkaya, Ant, Romain, Astrid and van Pottelsberghe de la Potterie, Bruno (2003), Surveying Technology-Based Small Firms - A perspective from Belgium. Region de Bruxelles-Capitale, Working Paper nr 23. Available: http://www.iir.hitu.ac.jp/file/WP03-23bruno.pdf. Extracted on 010504.

Brush, Candida G., Greene, Patricia G., Hart, Myra M. and Edelman, Linda F. (1997), 'Resource Configurations over the Life of Ventures', Frontiers of Entrepreneurship Research 1997. Available: http://www.babson.edu/entrep/fer/papers97/brush/bru1.htm. Extracted on 310504.

Chaganti, Radha and Greene, Patricia C. (2002), 'Who Are Ethnic Entrepreneurs: A Study of Entrepreneurs' Ethnic Involvement and Business Characteristics', Journal of Small Business Management 40 (2), pp. 126-143.

Dalhammar, Tobias (2004), Voices of entrepreneurship and small business - immigrant enterprises in Kista, Stockholm. Licentiate thesis, Royal Institute of Technology, Stockholm Sweden.

Davidsson, P. and Honig, B. (2003), 'The role of social and human capital among nascent entrepreneurs’, Journal of Business Venturing 18, pp. 301-331.

Fletcher, Denise (2003), 'Framing organizational emergence: discourse, identity and relationship', in Steyaert, Chris \& Hjorth, Daniel (eds.), New movements in entrepreneurship, Edward Elgar, pp. 125-142. 
Gartner, Gartner, William B. (1985). 'A Conceptual Framework for Describing the Phenomenon of New Venture Creation', Academy of Management Review, 10 (4), pp. 696-706.

Greene, Patricia G. and Brown, Terrence E. (1997), Resource Needs and the Dynamic Capitalism Typology, Journal of Business Venturing 12, pp. 161-173.

Greene, Patricia G., Brush, Candida and Brown, Terrence E. (1997), Resources in Small Firms: An Exploratory Study, Journal of Small Business Strategy 8, (2) pp. 25-40.

Holmquist, C. (2003). 'Is the medium really the message? Moving perspective from the entrepreneurial agent to the entrepreneurial action', in Steyaert, Chris \& Hjorth, Daniel (eds.), New movements in entrepreneurship, Edward Elgar.

Hytti, Ulla (2003), Stories of entrepreneurs - narrative construction of identities. Doctoral thesis, Turku School of Economics and Business Administration.

Institutet för tillväxtpolitiska studier, ITPS (2002). Nyföretagandet i Sverige 2000 och 2001. Available: http://www.itps.se/pdf/s2002_008.pdf. Extracted on 010902.

Johannisson, Bengt (2000), 'Modernising the Industrial District: Rejuvenation or Managerial Colonisation', in Taylor, Michael and Vatne, Eirik (eds.), The Networked Firm in Global World - small firms in new environments, Aldershot: Ashgate Publishing Limited, pp. 283-308.

Johannisson, Bengt (2001), 'Såsom i en spegel - invandrarföretagande att lära av', in NUTEK (2001b), Marginalisering eller integration - Invandrares företagande i svensk retorik och praktik, Stockholm: ADEBE Miljötryck.

Katz, Jerome and Gartner, William B. (1988), 'Properties of Emerging Organizations', Academy of Management Review 13 (3), pp. 429-441.

Keeble, D. and Wilkinson, F. (eds.), High-Technology Clusters, Networking and Collective Learning in Europe, Aldershot, UK: Ashgate Publishing Limited.

Keeble, David and Wilkinson, Frank (2000), 'High-Technology SMEs, Regional Clustering and Collective Learning: An Overview', in Keeble, D. and Wilkinson, F. (eds.), High-Technology Clusters, Networking and Collective Learning in Europe, Aldershot, UK: Ashgate Publishing Limited, pp. 1-20.

Kirzner, Israel (1973), Competition and Entrepreneurship, University of Chigaco Press.

Lichtenstein, Benyamin and Brush, Candida (1997), 'Salient Resources in New Ventures: A Longitudional Study of the Composition and Changes of Key Organizational resources in Three Entrepreneurial Firms', Frontiers of Entrepreneurship Research 1997. Available: http://www.babson.edu/entrep/fer/papers97/lichten/li.htm. Extracted on 310504.

Light, Ivan (1973). Ethnic Enterprise in America. University of California Press. 
Light, Ivan and Gold, Steven J. (2000), Ethnic Economies, San Diego, California: Academic Press.

Mitchell, Bruce (2003), 'Ethnic Entrepreneurship: Preliminary Findings from a South African Study’, Journal of Small Business an Entrepreneurship 17 (1), pp. 47-62.

Najib, Ali B. (1999). Myten om invandrarföretaget. En jämförelse mellan invandrarföretagande och övrigt företagande i Sverige. Rådet för arbetslivsforskning, Stockholm.

NUTEK (2001a), Invandrares företagande i Sverige: Kartläggning och analys, Sundbyberg: Alfa Print.

NUTEK (2001b), Marginalisering eller integration - Invandrares företagande i svensk retorik och praktik, Stockholm: ADEBE Miljötryck.

Penrose, E. (1959/1985), The Theory of the Growth of the Firm, New York: John Wiley \& Sons.

Pitelis, C. (ed.) (2002), The growth of the firm: the legacy of Edith Penrose. Oxford: Oxford University Press.

Pripp, Oscar (2001). Företagande i minoritet - Om etnicitet, strategier och resurser bland assyrier och syrianer i Södertälje. Mångkulturellt centrum 2001:5.

Ram, M. and Smallbone, D. (2001), Ethnic Minority Enterprise: Policy in Practice, UK DTI Small Business Service Research Report. Available: http://www.sbs.gov.uk/SBS_Gov_files/embf/Ethnic_Minority_Enterprise_Policy_In_Pra ctice.pdf. Extracted on 031105.

Samuelsson, M. (2001), 'Modeling the Nascent Venture Opportunity Exploitation Process Across Time’, Frontiers of Entrepreneurship Research 2001. Available: http://www.babson.edu/entrep/fer/Babson2001/I/IF/IF.htm. Extracted on 301103.

Saxenian, A. (2001), 'The role of Immigrant Entrepreneurs in New Venture Creation', in Schoonhoven, C., \& Romanelli, E. (eds.), The Entrepreneurship Dynamic. Stanford, USA: Stanford University Press, pp. 68-108.

Schoonhoven, C., \& Romanelli, E. (eds.), The Entrepreneurship Dynamic. Stanford, USA: Stanford University Press.

Statens offentliga utredningar, SOU (1999). Invandrare som företagare. Rapport 1999:49. Novum Grafiska AB, Stockholm.

Stinchcombe, A. L. (1965): Social Structure and Organizations. In: March, J.G. (ed.), Handbook of Organizations. Chicago: Rand McNally \& Company, pp.142-193.

Swedberg, Richard (2000). Entrepreneurship: The Social Science View. Oxford: Oxford University Press. 
Van de Ven, A. H. (1993). 'The Development of an Infrastructure for Entrepreneurship'. Journal of Business Venturing 8 (3), pp. 211-230.

Waldinger, Roger, Aldrich, Howard, Ward, Robin et al (1990). Ethnic Entrepreneurs. Immigrant Business in Industrial Societies. Sage Publications Inc.; Newbury Park.

Waldinger, Roger, Aldrich, Howard, Ward, Robin et al (2000). 'Ethnic Entrepreneurs'. In Swedberg, Richard (ed.). Entrepreneurship. The Social Science View, Oxford University Press, Oxford.

\section{Other sources}

Article at IDG's website. Available: http://www.idg.se/ArticlePages/200401/16/20040116125725_CS/20040116125725_CS.d bp.asp?s=022222222222222233333333333333001333333333333330011111111111111 $1 \&$ nolimit=true. Extracted on 100504.

Intranet of the municipality of Stockholm. Available: http://info.kista.stockholm.se/1.htm. Extracted on 170603.

Kista administration websites, Available: http://www.stockholm.se/kista; http://www.stockholm.se/templates/template_121.asp_Q_mainframe_E_template_120.as p_Q_number_E_13840_A_category_E_24_A_topcategory_E_189; http://www.stockholm.se/templates/template_121.asp_Q_mainframe_E_template_120.as p_Q_number_E_13840_A_category_E_24_A_topcategory_E_189. Extracted on 100504.

Website for company registers in Kista. Available: http://www.kista.com/foretagsregister.html?soktyp=f\&mid=007004). Extracted on 100504.

The website of the Swedish public television news program. Available: http://www.svt.se. Extracted on 010304.

Website of Uppsala municipality (Uppsala kommun). Available: http://www.uppsala.se/uppsala/templates/StandardPage 3260.aspx. Extracted on 090905. 